\title{
Rethinking the interplay between affluence and vulnerability to aid climate change adaptive capacity
}

\author{
Christine Eriksen ${ }^{1,2}$ (D) Gregory L. Simon ${ }^{3}$ (D) Florian Roth ${ }^{1,4}$ • \\ Shefali Juneja Lakhina ${ }^{2,16}$ (D) Ben Wisner $^{5,6} \cdot$ Carolina Adler $^{7}$ (D) Frank Thomalla $^{8}$ (D) \\ Anna Scolobig $^{9} \cdot$ Kate Brady $^{10,11}$ (D) $\cdot$ Michael Bründl $^{12} \cdot$ Florian Neisser $^{13}$ (DD • \\ Maree Grenfell ${ }^{14}$ (D) . Linda Maduz ${ }^{1} \cdot$ Timothy Prior $^{1,15}$
}

Received: 19 February 2020 / Accepted: 4 August 2020 / Published online: 26 August 2020

(C) The Author(s) 2020

\begin{abstract}
Affluence and vulnerability are often seen as opposite sides of a coin-with affluence generally understood as reducing forms of vulnerability through increased resilience and adaptive capacity. However, in the context of climate change and an increase in associated hazards and disasters, we suggest the need to re-examine this dynamic relationship - a complex association we define here as the Affluence-Vulnerability Interface (AVI). We review research in different national contexts to show how a more nuanced understanding of the AVI can (a) problematize the notion that increasing material affluence necessarily has a mitigating influence on social vulnerability, (b) extend our analysis of social vulnerability beyond low-income regions to include affluent contexts and (c) improve our understanding of how psychosocial characteristics influence people's vulnerability. Finally, we briefly outline three methodological approaches that we believe will assist future engagement with the AVI.
\end{abstract}

Keywords Climate change adaptation · Disaster resilience Natural hazards $\cdot$ Psychosocial coping capacity $\cdot$ Social vulnerability

\section{Introduction}

Despite economic and technological progress, floods, wildfires, drought and other natural hazards continue to impact communities in acute and prolonged ways around the world (Bouwer 2011; Hallegatte 2013; Mechler and Bouwer 2015; Thomalla et al. 2006). Exacerbated by climate change, a range of hazards are projected to become more

Christine Eriksen

christine.eriksen@sipo.gess.ethz.ch

Extended author information available on the last page of the article 
frequent and intense (IPCC 2014; Hoegh-Guldberg et al. 2018). The social and economic consequences of these climate-exacerbated hazards are likely to remain significant (Bouwer 2011; Eriksen and Ballard 2020; Kinoshita et al. 2016; Lucas et al. 2020; IPSP 2018).

In this evolving context, three related issues have become important to address. First, general material affluence (marked by an increase in per capita GDP and technological advancement) is not enough to mitigate climate change or to cope with the impacts of associated natural hazards, especially for people who are socially and/or physically marginalized (Fothergill and Peek 2004; Kelman 2015; Cinner et al. 2018). A problem of growing inequity is evident in all countries - high, medium and low income, especially in the context of rapid urban development processes. In some cases, increasing material affluence and access to resources may actually exacerbate pre-existing social vulnerabilities and produce new risks and vulnerabilities (Beck 1992; Simon 2014; Eadie and Su 2018). Even well-developed infrastructure, which we associate with technological advancement, can lead to segregation and inequality (Graham and Marvin 2001). Second, analysis of social vulnerability should extend beyond marginal and less economically developed regions to include acute forms of social precariousness and persistent climate change-related vulnerabilities in affluent settings. Third, a focus on material, financial and institutional resources has rendered important psychosocial characteristics underemphasized. Individual and community social and psychological attributes must also be acknowledged as influential, if not overriding, factors that influence social vulnerability to hazards in the face of climate change.

In the past decades, disaster risk reduction (DRR) policy has evolved from a sole emphasis on the mechanical and structural aspects of hazard mitigation to the guiding principle of disaster resilience. Resilience puts a strong emphasis on distributed capacities for disaster prevention, preparedness and recovery, and explicitly recognizes the need for social vulnerability analysis (Wisner et al. 2004; Pelling 2007; Tierney 2014; UN 2015; UNDRR 2015; Oliver-Smith et al. 2017). Nevertheless, challenges remain in how we engage in meaningful ways with historical, subjective and relational aspects of social vulnerability. Our essay speaks to this gap by providing theoretical insights and methodological pathways from research experiences in different national contexts. A particular focus on the USA, Switzerland and Australia demonstrates that affluent societies or places often have considerable and rising levels of inequality and it is the relative deprivation and marginalization of individuals and communities within these societies rather than affluence on the aggregate level, which result in vulnerable populations being hidden, forgotten or created.

In this paper, we draw on the concept of the Affluence-Vulnerability Interface (AVI), developed by Eriksen and Simon 2017, to examine these points with respect to individuals' and communities' adaptive capacity to climate change and associated natural hazards and disasters. We argue that the AVI is multifaceted and that this complexity should be more directly acknowledged in climate change and hazards research. The use of the AVI abbreviation should not be interpreted as an attempt to diminish these complexities. This focus enables us to (a) better understand why, in many contexts, the impacts of natural hazards remain high (Munich 2019) despite a general increase in global material wealth (Lange et al. 2018) and (b) suggest effective research and policy pathways that will help governments and emergency practitioners promote greater adaptive capacity to climate change-related hazards. 


\section{Vulnerability and affluence in current DRR research and practice}

According to Adger and Kelly $(1999,256)$, 'the extent to which individuals, groups or communities are 'entitled' to make use of resources determines the ability of that particular population to cope with and adapt to stress'. This perspective suggests that peoples' abilities to access and utilize resources will mediate adaptation to climatic changes and resulting environmental and social stressors. Yet, what exactly is meant by the term 'resources' (Abramson et al. 2010; Hobfoll 2012)? In recent research, material wealth is one common factor associated with peoples' capacities to cope with climate-exacerbated natural hazards (Fothergill and Peek 2004; Hallegatte 2013; Klomp and Valckx 2014; Mechler and Bouwer 2015; Schumacher and Strobl 2011). This view typically assumes a direct link between increased affluence (and associated access to material resources) and improved adaptive capacity. In other words, if we manage to increase the material wealth of an individual, community or nation, an increase in resilience will necessarily follow due to the availability of, for example, advanced infrastructure, technology and social services. In the following sections, we unpack and complicate this assumed linear relationship.

\subsection{An ongoing fixation with material coping capacities}

As an important element of risk, understanding what and who is vulnerable, and where vulnerable assets or people are located, has become a central aspect of DRR policies and research (Cutter and Finch 2008; Hearn Morrow 1999). Today, there is broad empirical evidence showing that the social characteristics of people and communities-including their social marginalization - have an indisputable influence on the severity of a disaster (Collins 2010; Haque and Etkin 2007; Ismail-Zadeh et al. 2017; Quarantelli 1992; Sword-Daniels et al. 2018; Wisner 1998). To some extent, this knowledge has been reflected in DRR policy documents and international strategies since the release of the Hyogo Framework for Action 2005-2015 (UNDRR 2005). These insights have led to important policy developments, such as the Sendai Framework for Disaster Risk Reduction (2015-2030), which place a strong emphasis on understanding and mitigating the underlying drivers of disaster risk (UNDRR 2015). Material disadvantages and vulnerability (of housing and critical infrastructure, for instance) are likewise considered to increase disaster risk in documents outlining climate change adaption strategies (UN 2015; UNFCCC 2015).

Following this perspective, the United Nations Office for Disaster Risk Reduction (UNDRR) defines social vulnerability as those 'characteristics determined by physical, social, economic and environmental factors or processes which increase the susceptibility of an individual, a community, assets or systems to the impacts of hazards' (UNDRR 2017). The Intergovernmental Panel on Climate Change (IPCC) positions social vulnerability as a 'determinant of risk', defining it as the 'susceptibility, sensitivity, and lack of resilience or capacities of [an] exposed system to cope with and adapt to extremes and non-extremes' (Cardona et al. 2012, 71). Thus, social vulnerability reflects that character of a place or population that limits its ability to cope with, or adapt to, disturbance, change or stress (Rumbach et al. 2016).

Although our understanding of social vulnerability in climate change and disaster contexts has evolved substantially from early assessments (Füssel and Klein 2006), a wider uptake of this knowledge has been slow. Castree (2017) and Haque and Etkin $(2007,271)$ constructively critique some members of the physical science community, as well as public sector decisionmakers who 'have not yet accepted the idea that understanding and using human and societal 
dimensions is equally or more important than trying to deal with and control nature through the use of technology'. There are four core reasons for this deficiency.

First, while social vulnerability is increasingly considered in climate change policy, most applied and region-specific management activities focus on emergency response and shortterm recovery. This is at the expense of targeted investment in long-term mitigation measures, which has been shown to both reduce social vulnerability to associated disasters and alleviate poverty (de Vet et al. 2019). Broadly speaking, economic growth is considered mainly in light of its mitigative influence on vulnerability, even though it can also generate social vulnerability and inequity (Eadie and Su 2018). This undervalues the role of development as a driver of risk (Thomalla et al. 2018). It also misses opportunities to examine how climate change affects health inequalities linked to access and distribution, which are distorted by affluence. This ranges from mortality from extreme events to food insecurity and access to public goods (Campbell et al. 2016; Myers et al. 2017). For example, Watts et al. (2015) argue that tackling climate change could be the greatest global health opportunity of the twenty-first century.

Second, a focus on strengthening material capacities for disaster response and recovery tends to overshadow the need to understand people's everyday lived experiences of social and physical vulnerabilities (Tanner et al. 2015). This trend is reinforced by various attempts to index and compare the vulnerability of communities, regions or whole nations in a fashion that fails to illuminate less obvious expressions of social vulnerability. Applied research tends to establish broad-scale vulnerability assessment strategies (regional or national scale), which are not fine-grained enough to assess heterogeneous households, diverse social conditions and individual characteristics. These widely circulated awareness-raising documents, such as reports by the IPCC (2014) and the Social Vulnerability Index (ATSDR 2017), lack historical, place-based assessments of policies, plans and decisions that are often complicit in the production of social vulnerabilities.

Third, a long tradition of social science scholarship that actually addresses the first two points (Wisner 1993; Wisner et al. 2004; Hewitt 1997; Liverman 1990) remains largely unknown to many climate change adaptation managers in public, private and non-profit sectors due to disciplinary divides and the inaccessibility of some academic writing styles, together with the unaffordability of many academic publications. These obstacles prevent the central points of this rich strand of research from being taken up by practitioners.

Fourth, understanding what actually causes social vulnerability in diverse contexts is extremely challenging. Social and psychological characteristics of individual people, communities and places are multifaceted, methodologically difficult to access and costly to measure. For example, individuals and communities may have excellent coping capacities with respect to some climate change impacts while simultaneously being vulnerable to others. It is difficult to incorporate these complex elements into the often synoptic nature of current social vulnerability analyses (Brown and Westaway 2011).

\subsection{The undervalued role of non-material coping capacities}

Affluence is typically understood as the ability of an individual or community to achieve a financial status that enables a corresponding level of access to material resources and/or assets (Adger 2006; Adger and Kelly 1999; Smit and Wandel 2006). Increased material affluenceparticularly growing wealth and technological advancement-represents the social change that is most often associated with reduced hazard vulnerability, increased resilience, and improved adaptation and coping capacity (Mcleod and Kessler 1990; Thomalla et al. 2006). To be sure, 
this is often the case, as these material resources can (at least theoretically) be easily converted into risk-mitigating adaptations, such as buying a car that enables a family to evacuate from a hurricane or building an embankment to mitigate against sea-level rise. The experience of unequal risk during Hurricane Katrina in 2005 highlighted how affluent people and places in New Orleans, Louisiana, USA, were better able to cope before, during and after the hurricane (Cutter and Emrich 2006; Fothergill and Peek 2015).

Yet, a growing body of robust research examining the formation of social vulnerability demonstrates that a focus on material wealth alone does not always adequately capture the interplay between climate-exacerbated natural hazards, social vulnerability and loss (Aldrich 2012; Barnett et al. 2016; Collins 2010; Collins and Bolin 2009; Eriksen and Simon 2017; Kuhlicke et al. 2011; Roth et al. 2018; Haworth et al. 2019). In taking a more cautious approach when describing trends in social vulnerability, it is possible to demonstrate that climate change-related risks and vulnerabilities are not improving proportional to levels of economic development (Eriksen 2019a).

Resources influencing the coping capacity of communities and individuals related to natural hazards can be material (e.g. finances, assets, technologies), psychosocial (e.g. emotions, social networks, belonging, social cohesion, beliefs, local knowledge) and institutional (e.g. political power, governance functionality) (Hobfoll 2012; Simon 2014; Sword-Daniels et al. 2018; Lakhina et al. 2019). Material and non-material resources - also referred to as 'tangible' and 'intangible' (Tapsell et al. 2002; de Andrade and Szlafsztein 2018) - may interact to influence institutional resources and social vulnerabilities. Meanwhile, the existence, capacity and accountability of government institutions (local to national) have a strong influence on coping capacity. We use the term 'coping capacity' here to reference the ability of people, organizations and systems, using available skills and resources, to manage adverse conditions, risk or disasters (Gaillard 2010).

We argue below that expanding our understanding of the relationship between affluence and social vulnerability is important and suggest that this association is not linear. Rather, the relationship must be understood as dynamic and complex in the evolving context of climate change and its increasingly frequent and severe consequences for communities worldwide.

\section{The Affluence-Vulnerability Interface: three critical insights and proposed research directions}

With the objective of generating a more robust and comprehensive understanding of the AVI across a range of contexts and locations, we now reflect on insights from a number of independent research projects from different national contexts. The AVI was initially developed as a process-based analytical framework to unpack the concomitant yet competing social conditions that shaped short- and long-term experiences of wildfire recovery in California, USA. The study results demonstrated that:

Explicitly integrating and examining the role of, for example, affluence and privilege, risk and vulnerability, age and disability within a single study, instead of just highlighting differences and disparities ... recognizes class and affluence as a financial status that intersects with other cultural practices, identities and politics, which are based on ideological norms and are lived but often generalized and/or unacknowledged. (Eriksen and Simon 2017, 296-297) 
We expand on these insights to demonstrate the broader analytic and methodological utility (summarized in Table 1) of the AVI in (a) problematizing the frequently assumed linear and mitigative relationship between affluence and social vulnerability (Section 3.1), (b) extending analysis of social vulnerability to include acute climate change and related hazard vulnerabilities in affluent settings (Section 3.2) and (c) improving our understanding of the vital role of psychosocial coping capacity in formulating socially responsive DRR policy and practice (Section 3.3).

\subsection{AVI insight 1: the co-production of affluence and social vulnerability and the merits of historical-structural analysis}

Focusing on the relationship between affluence and social vulnerability entails systematically examining how development processes, which enable cities and regions to thrive and become wealthier, may also increase individual and collective vulnerability to climate change and natural hazards. This perspective shows how affluence can play a central role in the creation of both disaster resilience and vulnerability. Here, we briefly highlight the latter. It is clear that increased material wealth will in many cases lessen conditions of social vulnerability. Yet, if we understand affluence to have only a mitigating influence, then we are likely to miss circumstances where vulnerabilities and forms of social risk exist as a consequence of policies aimed at increasing economic growth and material wealth (Beck 1992).

Historical analysis of the lucrativeness of suburban landscapes provides an insightful example of how affluence and social vulnerability to climate-exacerbated hazards, such as wildfires and floods, are co-produced (Simon 2014; Collins 2010; Kaufman 2017). Suburban landscapes in the Western USA simultaneously produce and maintain financial benefits, risk and vulnerability (Simon 2017). The pursuit of affluent neighbourhoods and construction industry profits at the city's edge in the USA (and elsewhere) are not benign. Over time, the generation of material benefits have coincided with the production and maintenance of considerable risks related to wildfires, as homes and lives are put in harm's way with the expansion of cities into historically fire-prone areas (Kramer et al. 2018). This includes lowincome trailer parks, positioned in high-risk locations, for those who cannot afford more expensive city homes (Rumbach et al. 2020).

Such historical insights illuminate how social vulnerability is generated within landscapes that are intentionally altered, developed and maintained in a manner that retains their productivity, or desired economic purpose, for cities (property tax revenue), developers (construction contracts) and landholders (subdivide-and-sell) alike. Social vulnerability is much more than simply a produced outcome or material inscription (Wisner et al. 2004; Oliver-Smith et al. 2017). Employing a historical-structural research agenda reveals how diverse vulnerabilities unfold as part of a region's broader historical development, which feed into persistent social injustice, inequality and vulnerability. When historically minded research is incorporated into one's practice (e.g. by using recent and archived land use planning and economic development documents), it is easier to highlight persistent root causes of social vulnerability. As with all analysis of complex systems, there are caveats attached to this approach, which require careful attention. Historical-structural analysis can lead to the discovery of secondary and tertiary cascading vulnerability impacts within other populations and locations. Further research is required to probe these 'knock on effects' of change, which are associated with the coproduction of affluence and risk. 
Table 1 Analytical approaches recommended to investigate the Affluence-Vulnerability Interface (AVI), adaptive capacity and climate change

\begin{tabular}{|c|c|c|c|}
\hline & \multicolumn{3}{|l|}{ Analytic approaches } \\
\hline & Historical-structural & Intersectional & Psychosocial \\
\hline Aims & $\begin{array}{l}\sim \text { Identify historical and } \\
\text { structural drivers } \\
\text { influencing the } \\
\text { co-production of afflu- } \\
\text { ence and vulnerability } \\
\sim \text { Systematically examine } \\
\text { and connect past, } \\
\text { present and future } \\
\text { development processes }\end{array}$ & $\begin{array}{l}\sim \text { Locate experiences of } \\
\quad \text { vulnerability amidst } \\
\text { affluence } \\
\sim \text { Generate insights into } \\
\text { concomitantly held } \\
\text { experiences, conditions } \\
\text { and identities }\end{array}$ & $\begin{array}{l}\text { Understand people's } \\
\text { coping capacities by } \\
\text { examining how } \\
\text { psychological factors } \\
\text { and the surrounding } \\
\text { community context } \\
\text { (beyond material } \\
\text { wealth) influence } \\
\text { well-being and ability } \\
\text { to function }\end{array}$ \\
\hline Scales of analysis & $\begin{array}{l}\text { Often begins with the } \\
\text { policy realm and } \\
\text { extends to policy } \\
\text { implementation, } \\
\text { impacts and outcomes }\end{array}$ & $\begin{array}{l}\text { Often begins with } \\
\text { societal or community } \\
\text { scales and extends to } \\
\text { households and } \\
\text { individuals }\end{array}$ & $\begin{array}{l}\text { Often begins with } \\
\text { individuals and } \\
\text { households and extends } \\
\text { to neighbourhood and } \\
\text { community scales }\end{array}$ \\
\hline $\begin{array}{l}\text { Insights from AVI analysis } \\
\text { of factors that increase or } \\
\text { reduce vulnerability to } \\
\text { climate-exacerbated } \\
\text { hazards and disasters }\end{array}$ & $\begin{array}{l}\sim \text { Urban development with } \\
\text { significant financial } \\
\text { benefits for some } \\
\text { simultaneously } \\
\text { produces considerable } \\
\text { risks for others, as } \\
\text { homes and lives are put } \\
\text { in harm's way when } \\
\text { cities expand into more } \\
\text { hazard-prone areas } \\
\text { Diverse vulnerabilities } \\
\text { unfold as part of a } \\
\text { region's broader } \\
\text { historical development, } \\
\text { which may feed into } \\
\text { persistent social } \\
\text { injustices, inequalities } \\
\text { and vulnerabilities that } \\
\text { are reproduced during } \\
\text { disaster recovery and } \\
\text { rebuilding processes }\end{array}$ & $\begin{array}{l}\text { Pockets of } \\
\text { marginalization within } \\
\text { affluent communities, } \\
\text { such as undocumented/ } \\
\text { irregular/ seasonal } \\
\text { migrants who may be } \\
\text { unacknowledged in } \\
\text { climate change } \\
\text { mitigation and } \\
\text { adaptation efforts } \\
\text { Affluent individuals or } \\
\text { households who may } \\
\text { be socially } \\
\text { disadvantaged due to } \\
\text { conditions, such as age, } \\
\text { limited mobility, poor } \\
\text { health or racism, may } \\
\text { not derive any benefits } \\
\text { from their otherwise } \\
\text { secure financial } \\
\text { position } \\
\text { Everyday ('mundane') } \\
\text { vulnerabilities that exist } \\
\text { in 'plain sight', such as } \\
\text { language barriers, } \\
\text { access or functional } \\
\text { needs, are often } \\
\text { overlooked by official } \\
\text { disaster mitigation } \\
\text { efforts }\end{array}$ & $\begin{array}{l}\text { Social cohesion can aid } \\
\text { the development of } \\
\text { mitigative behaviour } \\
\text { and increase } \\
\text { psychosocial coping } \\
\text { capacities, for example, } \\
\text { through the work of } \\
\text { mutual aid groups, } \\
\text { voluntary networks and } \\
\text { neighbourhood } \\
\text { associations } \\
\sim \text { Marginalization and } \\
\text { discrimination } \\
\text { underpinned by social } \\
\text { characteristics are often } \\
\text { magnified in disasters, } \\
\text { undermining people's } \\
\text { ability to cope } \\
\sim \text { When marginalized } \\
\text { voices are } \\
\text { acknowledged and } \\
\text { included in emergency } \\
\text { management processes, } \\
\text { communities and } \\
\text { institutions often } \\
\text { benefit from the diverse } \\
\text { forms of embodied and } \\
\text { embedded knowledge }\end{array}$ \\
\hline
\end{tabular}

Source: authors 


\subsection{AVI insight 2: locating vulnerability amidst affluence and the benefits of intersectional analysis}

Expanding our understanding of the relationship between affluence and social vulnerability also entails exploring sites of acute vulnerability within affluent areas. Rich empirical evidence suggests that social vulnerability is a significant root cause of most disasters (see Roth et al. 2017 for an overview). However, social vulnerability to natural hazards is highly context specific. Of particular relevance here are pockets of disadvantaged groups susceptible to climate change, who live alongside less vulnerable groups in highly affluent communities (Eriksen and Simon 2017; Roth et al. 2018; Simon 2014; Wisner 1998; Lakhina et al. 2019; Maidl and Buchecker 2015).

For example, the city of Zürich in Switzerland is consistently ranked as one of the most liveable and wealthy on the planet. Yet, it is also home to a growing number of socially vulnerable people who live in informal and/or precarious housing (Prior et al. 2017; Roth et al. 2018). Factors that influence social vulnerability include the following: (a) people living in social housing areas close to flood zones; (b) non-German-speaking residents unable to understand risk information provided by the authorities in German, or who are unfamiliar with Switzerland's system of hazard-specific siren warnings; (c) the elderly; and (d) sans papiers migrants (undocumented status) who work for cash but are not registered in the city and are therefore unacknowledged in climate change mitigation and adaptation efforts. Social workers highlighted that people socially vulnerable in their everyday lives (because of mobility or health issues, isolation, mental illness, low income, etc.) were disproportionately more likely to be impacted by natural hazards, in part because 'mundane' vulnerabilities that exist in 'plain sight' often are overlooked by official disaster mitigation efforts (Roth et al. 2018).

On the one hand, these overlooked vulnerabilities may point to pockets of marginalization within affluent communities (e.g. the sans papiers in Zürich). On the other hand, these vulnerabilities may arise when a relatively safe (perhaps even affluent) individual or household is disadvantaged socially due to conditions that undercut any benefits derived from their otherwise secure financial position. Examples might include the non-ambulatory residents, the elderly or young children who have difficulty evacuating; people suffering from mental health issues who may find it difficult to recover from, or cope with, the aftermath of a disaster; or people of colour who face discrimination within the vast legal and insurance landscape confronting disaster survivors and displaced people (Astill and Miller 2016; Farbotko and Lazrus 2012; Fothergill and Peek 2015; Lister 2014; Simon 2017).

In light of these social complexities, we suggest that researchers and emergency managers alike utilize intersectional climate hazards analysis (Kaijser and Kronsell 2014; Walker et al. 2019). Intersectional analysis can provide a useful framework for generating insights into concomitantly held experiences, conditions and identities. For example, it can highlight how expressions of affluence and social vulnerability overlay or intersect one another, thereby illuminating and disentangling the complicated social fabric confronting climate change and DRR efforts (Eriksen and Simon 2017). There is a need for further research that undertakes nuanced analysis of affluent contexts in order to tease out particular cultural and historical manifestations of social vulnerability. This includes a focus on the manifestation of differing levels of affluence and vulnerability experienced by different strata of the rapidly expanding middle class in most countries of the world (e.g. see Zuniga and Campos 2013). 


\subsection{AVI insight 3: understanding social vulnerability through analysis of psychosocial coping capacity}

A third approach to examining the AVI involves broadening our assessment of what social factors influence individual hazard vulnerabilities. Specifically, we believe that it is important to acknowledge not only material coping capacities (which privilege the influence of affluence) but also psychosocial coping capacities, which shape the acute and chronic social impacts of disasters (Tapsell 2010). We consider psychosocial coping capacity to be the combined influence of psychological factors and the surrounding community context on an individual's physical and mental wellness and their ability to function (Eyre 2017).

Recent studies demonstrate different dimensions of psychosocial coping capacity and their influence on social vulnerability and adaptation to climate-related hazards. On the one hand, socio-cultural narratives can create conflicting perceptions of, and responses to, climate change, which legitimize unequal resource distribution and justify the suppression or capitalisation of both sub-cultural and individual risk perceptions (Rühlemann and Jordan 2019). On the other hand, social cohesion, particularly characteristics like 'sense of community' and 'collective problem solving', can act as community-based factors (i.e. social resources) that support the development of mitigative behaviour (i.e. practical resources) and cognitive abilities (i.e. psychological resources). Together, these factors have been shown to increase psychosocial coping capacities among residents at risk of wildfire in Southeast Australia and the US West (Paveglio and Edgeley 2017; Prior and Eriksen 2013). Among disaster recovery workers, research has also shown that factors supporting psychosocial coping capacity, such as the ability to confide, reflect, debate, grow and heal through mental, spiritual and physical safe spaces, are crucial for their continued ability to cope and care amidst social and environmental uncertainty (Eriksen 2019b; see also Brady 2011). These same factors increase psychosocial coping capacities and overall well-being in communities with greater economic equality and high social cohesion, suggesting that 'relative' well-being is more important than 'absolute' wealth in reducing social vulnerabilities (Wilkinson 2002; Pickett and Wilkinson 2015).

Equally critical to any understanding of coping capacity is the matter of marginalizationi.e. the treatment of a person, group or concept as insignificant or peripheral due to social characteristics, such as age, gender, sexuality, ethnicity, race, disability, class or education (Wisner et al. 2004). Marginalization is closely related to discrimination - processes, such as racism, homophobia, sexism and ageism, that undermine psychosocial coping capacity. Social characteristics, marginalization and discrimination intersect in everyday life to make people more or less resilient: The more ways a person is marginalized, the less likely they are to have adequate resources to respond and recover in a disaster (Eriksen 2019a). When disaster strikes, the pressure on socially marginalized groups is therefore often magnified and may inhibit access to available support services (Wisner 2010; Collins 2010; Gorman-Murray et al. 2014; Haworth et al. 2019; Pacoma and Delda 2019; Craig et al. 2019).

Insights from the Northern Territory of Australia demonstrate how the socially marginalized status of Indigenous peoples and their belief systems increases social vulnerability to climate change-related hazards and disasters more broadly (Veland et al. 2013). This is because the perspectives, values and psychosocial coping capacities of these communities tend to be systematically ignored in emergency management and climate change adaptation initiatives. Instead, the results of the ongoing disaster of colonization in Indigenous Nationspoverty, ill health and welfare dependence - are labelled as the primary contributors to hazard vulnerability. When these marginalized voices are acknowledged and incorporated, the 
resulting emergency management processes have been shown to benefit significantly from the psychosocial coping capacities Indigenous peoples have developed over millennia, often in response to social and environmental uncertainty (Veland et al. 2010; Gaillard et al. 2008; Gaillard 2010; Christianson et al. 2013; Eriksen and Hankins 2014).

Social vulnerability assessments focusing only on material coping capacity are insufficient to explain how people experience and adapt to climate-exacerbated natural hazards and disasters because they do not acknowledge systemic social injustices, such as marginalization and discrimination. In order to plan for, and respond to, threats of the future, knowledge about material coping capacity must be complemented with an understanding of psychosocial coping capacity. Furthermore, given increased human mobility, additional research is required to determine whether, genealogically, locations are essential to 'sense of community', as they have been in most places until the late twentieth century. This includes the psychosocial coping capacity of refugees and climate migrants whose numbers are growing and who must periodically seek refuge in unfamiliar places (Farbotko and Lazrus 2012; Lewis and Wisner 1981; Lakhina et al. 2019)?

Understanding such conditions will require greater reliance on qualitative and narrative methods, such as embedded ethnographies, in-depth interviews, participatory mapping and action research, which can explain processes of both social marginalization and social cohesion (Scolobig et al. 2015). These methods also unpack related psychosocial conditions, such as (dis)trust, discrimination, loneliness and despair, which can exist independently of material affluence, yet are significant in the context of peoples' vulnerability and resilience to climate change.

\section{Conclusion}

In this essay, we have examined the complex and multifaceted relationship between affluence and social vulnerability in the context of climate change and associated hazards and disasters. Our analysis shows that the AVI is a dynamic process by which vulnerability and affluence mutually interact to determine people's lived experiences of risks and disasters. This suggests that material wealth can have both a mitigative and generative influence on social vulnerability. The AVI is also a condition of spatial difference where acute forms of social vulnerability are nested within and alongside areas of considerable material wealth. They are thus often hidden from view within conventional social vulnerability indices that inform much climate change and DRR policy and practice. Furthermore, the AVI is an area of intentional inquiry that can provide useful insights about individual and community hazard vulnerability while drawing attention to psychosocial coping capacities critical to effective emergency management.

In order to further investigate these aspects of the AVI, and to better respond to future threats, we recommend that the three methodological approaches discussed above and summarized in Table 1-historical-structural analysis, intersectional analysis and psychosocial analysis - are given further attention within research, policy and disaster management settings. We believe that using these approaches to investigate the AVI will augment DRR efforts to improve individuals' and communities' adaptive capacity to climate change and associated natural hazards in the years ahead.

Of course, there are many ways material, non-material and institutional resources mediate the relationship between affluence and vulnerability. These dynamics, and the particular forms of social vulnerability they produce, will always be context dependent. Thus, one should not assume that the AVI insights and examples discussed in this essay are perfectly transferable to 
all locations. Rather, we have explored new conceptual ground and proposed the AVI, with its three critical insights, as a useful heuristic that may assist researchers and practitioners responding to disasters and uncertainty associated with changing social, political and environmental climates at different scales.

Funding information Open Access funding provided by Swiss Federal Institute of Technology Zurich.

Open Access This article is licensed under a Creative Commons Attribution 4.0 International License, which permits use, sharing, adaptation, distribution and reproduction in any medium or format, as long as you give appropriate credit to the original author(s) and the source, provide a link to the Creative Commons licence, and indicate if changes were made. The images or other third party material in this article are included in the article's Creative Commons licence, unless indicated otherwise in a credit line to the material. If material is not included in the article's Creative Commons licence and your intended use is not permitted by statutory regulation or exceeds the permitted use, you will need to obtain permission directly from the copyright holder. To view a copy of this licence, visit http://creativecommons.org/licenses/by/4.0/.

\section{References}

Abramson D, Stehling-Ariza T, Park Y, Walsh L, Culp D (2010) Measuring individual disaster recovery: a socioecological framework. Disaster Med Public Health Prepare 4(S1):S46-S54

Adger WN (2006) Vulnerability. Glob Environ Chang 16(3):268-281

Adger WN, Kelly PM (1999) Social vulnerability to climate change and the architecture of entitlements. Mitig Adapt Strateg Glob Chang 253-266

Aldrich D (2012) Building resilience: social capital in post-disaster recovery. University of Chicago Press, Chicago

Astill S, Miller E (2016) The trauma of the cyclone has changed us forever: self-reliance, vulnerability and resilience among older Australians in cyclone-prone areas. Ageing Soc 38(2):403-429

ATSDR (2017) The social vulnerability index (SVI). https://svi.cdc.gov/. Accessed 17 February 2020

Barnett J, Tschakert P, Head L, Adger NW (2016) A science of loss. Nat Clim Chang 6:976-978

Beck U (1992) Risk society: towards a new modernity. Sage, London

Bouwer LM (2011) Have disaster losses increased due to anthropogenic climate change? Bull Am Meteorol Soc 92(1):39-46

Brady K (2011) Churchill fellowship report: best practice psychosocial recovery following emergencies. Churchill Trust: https://www.churchilltrust.com.au/fellow/?id=PR0013355. Accessed 24 August 2020

Brown K, Westaway E (2011) Agency, capacity, and resilience to environmental change: lessons from human development, well-being, and disasters. Annu Rev Environ Resour 36(1):321-342

Campbell BM, Vermeulen SJ, Aggarwal PK et al (2016) Reducing risks to food security from climate change. Global Food Security 11:34-43

Cardona OOD, van Aalst MK, Birkmann J, Fordham M, McGregor G, Perez R, Pulwarty RS, et al. (2012) Determinants of risk : exposure and vulnerability. In: field CB, Barros V, stocker TF, Qin D, Dokken DJ, Ebi KL, et al. Managing the risks of extreme events and disasters to advance climate change adaptation - a special report of working groups I and II of the Intergovernmental Panel on Climate Change (IPCC) Cambridge University Press, Cambridge, pp 65-108. https://doi.org/10.1017/CBO9781139177245.005

Castree N (2017) Speaking for the 'people disciplines': global change science and its human dimensions. The Anthropocene Review 4(3):160-182

Christianson A, McGee TK, L'Hirondelle L (2013) How historic and current wildfire experiences in an aboriginal community influence mitigation preferences. Int J Wildland Fire 22(4):527-536

Cinner JE, Adger WN, Allison EH, Barnes ML, Brown K, Cohen PJ, Gelcich S et al (2018) Building adaptive capacity to climate change in tropical coastal communities. Nat Clim Chang 8(2):117-123

Collins TW (2010) Marginalization, facilitation, and the production of unequal risk: the 2006 Paso del Norte floods. Antipode 42(2):258-288

Collins TW, Bolin B (2009) Situating hazard vulnerability: people's negotiations with wildfire environments in the U.S. southwest. Environ Manag 44(3):441-455

Craig L, Craig N, Calgaro E, Dominey-Howes D, Johnson K (2019) People with disabilities: becoming agents of change in disaster risk reduction. In: Rivera FI (edn) emerging voices in natural hazards research pp 327-56. https://doi.org/10.1016/C2017-0-03916-2

Cutter SL, Emrich CT (2006) Moral hazard, social catastrophe: the changing face of vulnerability along the hurricane coasts. Ann Am Acad PoliticalSocial Sci 604(1):102-112 
Cutter SL, Finch C (2008) Temporal and spatial changes in social vulnerability to natural hazards. Proc Natl Acad Sci U S A 105(7):2301-2306

de Andrade MMN, Szlafsztein CF (2018) Vulnerability assessment including tangible and intangible components in the index composition: an Amazon case study of flooding and flash flooding. Sci Total Environ 630:903-912

de Vet E, Eriksen C, Booth K, French S (2019) An unmitigated disaster: shifting from response and recovery to mitigation for an insurable future. Int J Disaster Risk Sci 10(2):179-192

Eadie P, Su Y (2018) Post-disaster social capital: trust, equity, bayanihan and Typhoon Yolanda. Disaster Prev Manag: An International Journal 27(3):334-345

Eriksen C (2019a) Human vulnerability to 'natural' disasters: a case study of Hurricane Katrina. Geogr Rev $33(2): 2-5$

Eriksen C (2019b) Coping, caring and believing: the embodied work of disaster recovery workers. Emotion, space and society $32(100592)$

Eriksen C, Ballard S (2020) Alliances in the Anthropocene: fire, plants and people. Palgrave Macmillan, Pivot

Eriksen C, Hankins DL (2014) The retention, revival and subjugation of indigenous fire knowledge through agency fire fighting in Eastern Australia and California, USA. Soc Nat Resour 27(12):1288-1303

Eriksen C, Simon GL (2017) The Affluence-Vulnerability Interface: intersecting scales of risk, privilege and disaster. Environ Plan A 49(2):293-313

Eyre A (2017) Lessons in providing psychosocial support: a review of three post-disaster programs. Australian disaster resilience knowledge hub, pp 30-34. Australian Institute for Disaster Resilience. https://knowledge. aidr.org.au/resources/ajem-jul-2017-lessons-in-providing-psychosocial-support-a-review-of-threepostdisaster-programs/. Accessed 17 February 2020

Farbotko C, Lazrus H (2012) The first climate refugees? Contesting global narratives of climate change in Tuvalu. Glob Environ Chang 22:382-390

Fothergill A, Peek LA (2004) Poverty and disasters in the United States: a review of recent sociological findings. Nat Hazards 32(1):89-110

Fothergill A, Peek LA (2015) Children of Katrina. University of Texas Press, Austin

Füssel H, Klein RJT (2006) Climate change vulnerability assessments: an evolution of conceptual thinking. Clim Chang 75:301-329

Gaillard JC (2010) Vulnerability, capacity and resilience: perspectives for climate and development policy. J Int Dev 22(2):218-232

Gaillard JC, Clavé E, Vibert O, Azhari D, Denain JC, Efendi Y et al (2008) Ethnic groups' response to the 26 December 2004 earthquake and tsunami in Aceh, Indonesia. Nat Hazards 47(1):17-38

Gorman-Murray A, Morris S, Keppel J, McKinnon S, Dominey-Howes D (2014) The LGBTI community in the 2011 Queensland floods: marginality, vulnerability and resilience. LES Online: Digital Journal on Lesbian Issues 6(1):4-20

Graham S, Marvin S (2001) Splintering urbanism: networked infrastructures, technological mobilities and the urban condition. Routledge, New York

Hallegatte S (2013) Economic growth and risk taking: is it rational to suffer from increasing disaster losses? (September 5, 2013). Review of Environment, Energy and Economics (Re3), Available at SSRN: https://ssrn.com/abstract=2321165. Accessed 17 February 2020

Haque CE, Etkin D (2007) People and community as constituent parts of hazards: the significance of societal dimensions in hazards analysis. Nat Hazards 41(2):271-282

Haworth BT, Eriksen C, McKinnon S (2019) Online tools can help people in disasters, but do they represent everyone? The conversation. 30 May. https:/theconversation.com/online-tools-can-help-people-in-disastersbut-do-they-represent-everyone-116810. Accessed 17 February 2020

Hearn Morrow B (1999) Identifying and mapping community vulnerability. Disasters 23(1):1-18

Hewitt K (1997) Regions of risk. A geographical introduction to disasters, Addison Wesley Longman

Hobfoll SE (2012) Conservation of resources and disaster in cultural context: the caravans and passageways for resources. Psychiatry: Interpersonal and Biological Processes 75(3):227-232

Hoegh-Guldberg O, Jacob D, Taylor M, Bindi M, Brown S, Camilloni I, Diedhiou A, Djalante R, Ebi KL, Engelbrecht F, Guiot J, Hijioka Y, Mehrotra S, Payne A, Seneviratne SI, Thomas A, Warren R, Zhou G (2018) Impacts of $1.5^{\circ} \mathrm{C}$ global warming on natural and human systems. In: Global Warming of $1.5^{\circ} \mathrm{C}$. An IPCC Special Report on the impacts of global warming of $1.5^{\circ} \mathrm{C}$ above pre-industrial levels and related global greenhouse gas emission pathways, in the context of strengthening the global response to the threat of climate change, sustainable development, and efforts to eradicate poverty. Eds. Masson-Delmotte V, Zhai P, Pörtner HO, Roberts D, Skea J, Shukla PR, Pirani A, Moufouma-Okia W, Péan C, Pidcock R, Connors S, Matthews JBR, Chen Y, Zhou X, Gomis MI, Lonnoy E, Maycock T, Tignor M, Waterfield T. pp 175-311. https://www.ipcc.ch/sr15 
Intergovernmental Panel on Climate Change (IPCC) (2014) Climate Change 2014: synthesis report. Contribution of Working Groups I, II and III to the Fifth Assessment Report of the Intergovernmental Panel on Climate Change [Core Writing Team, Pachauri RK, Meyer LA (eds.)]. IPCC, Geneva, Switzerland, 151pp

International Panel on Social Progress (IPSP) (2018) Rethinking society for the $21^{\text {st }}$ Century. https://www.ipsp. org/. Accessed 17 February 2020

Ismail-Zadeh AT, Cutter SL, Takeuchi K, Paton D (2017) Forging a paradigm shift in disaster science. Nat Hazards 86:969-988

Kaijser A, Kronsell A (2014) Climate change through the lens of intersectionality. Environ Politics 23(3):417-433

Kaufman A (2017) Houston flooding always hits poor, non-White neighborhoods hardest Huffpost 29 August. https:/www.huffpost.com/entry/houston-harvey-environmental-justice_n_59a41c90e4b06d67e3390993. Accessed 17 February 2020

Kelman I (2015) Climate change and the Sendai framework for disaster risk reduction. Int JDisaster Risk Sci 6(2):117-127

Kinoshita AM, Chin A, Simon GL, Briles C, Hogue TS, O’Dowd AP, Gerlak AK, Uribe Albornoz A (2016) Wildfire, water, and society: toward integrative research in the "Anthropocene". Anthropocene 16:16-27

Klomp J, Valckx K (2014) Natural disasters and economic growth: a meta-analysis. Glob Environ Chang 26: 183-195

Kramer HA, Mockrin MH, Alexandre PM, Stewart SI, Radeloff VC (2018) Where wildfires destroy buildings in the US relative to the wildland-urban interface and national fire outreach programs. Int $\mathrm{J}$ Wildland Fire 27(5):329-341

Kuhlicke C, Scolobig A, Tapsell S, Steinführer A, De Marchi B (2011) Contextualizing social vulnerability: findings from case studies across Europe. Nat Hazards 58(2):789-810

Lakhina SJ, Eriksen C, Thompson J, Aldunate R, McLaren J, Reddy S (2019) People from refugee backgrounds contribute to a disaster-resilient Illawarra. Austr J Emerg Manag 34(2):19-20

Lange GM, Wodon Q, Carey K (2018) The changing wealth of nations 2018: building a sustainable future. World Bank, Washington

Lewis H, Wisner B (1981) Refugee rehabilitation in Somalia. Development project, consulting report no. 6. University of Wisconsin, Madison, WI

Lister M (2014) Climate change refugees. Crit Rev Int Soc Pol Phil 17:618-634

Liverman DM (1990) Drought impacts in Mexico: climate, agriculture, technology, and land tenure in Sonora and Puebla. Ann Assoc Am Geogr 80(1):49-72

Lucas C, Eriksen C, Bowman, D (2020) A crisis of underinsurance threatens to scar rural Australia permanently. The Conversation. https://theconversation.com/a-crisis-of-underinsurance-threatens-to-scar-rural-australiapermanently-129343. Accessed 16 February 2020

Maidl E, Buchecker M (2015) Raising risk preparedness by flood risk communication. Nat Hazards Earth Syst Sci 15(7):1577-1595

Mcleod J, Kessler R (1990) Socioeconomic status differences in vulnerability to undesirable life events. J Health Soc Behav 31(2):162-172

Mechler R, Bouwer LM (2015) Understanding trends and projections of disaster losses and climate change: is vulnerability the missing link? Clim Chang 133(1):23-35

Munich RE (2019) Extreme storms, wildfires and droughts cause heavy nat cat losses in 2018. https://www. munichre.com/en/company/media-relations/media-information-and-corporate-news/mediainformation/2019/2019-01-08-extreme-storms-wildfires-and-droughts-cause-heavy-nat-cat-losses-in-2018. html. Accessed 24 August 2020

Myers SS, Smith MR, Guth S et al (2017) Climate change and global food systems: potential impacts on food security and undernutrition. Annu Rev Public Health 38(1):259-277

Oliver-Smith A, Alcántara-Ayala I, Burton I, Lavell A (2017) The social construction of disaster risk: seeking root causes. Int J Disaster Risk Reduct 22:469-474

Pacoma AJU, Delda JS (2019) Social capital in the post-Haiyan setting: the role of local and translocal ties in building household resilience. Int J Disaster Risk Reduct 40:101250

Paveglio TB, Edgeley C (2017) Community diversity and hazard events: understanding the evolution of local approaches to wildfire. Nat Hazards 87(2):1083-1108

Pelling M (2007) Learning from others: the scope and challenges for participatory disaster risk assessments. Disasters 31(4):373-385

Pickett KE, Wilkinson RG (2015) Income inequality and health: a causal review. Soc Sci Med 128:316-326

Prior T, Eriksen C (2013) Wildfire preparedness, community cohesion and social-ecological systems. Glob Environ Chang 23(6):1575-1586

Prior T, Roth F, Maduz L, Scafetti F (2017) Mapping social vulnerability in Switzerland: a pilot study on flooding in Zürich. ETH Zurich, Switzerland. https://css.ethz.ch/content/specialinterest/gess/cis/center-for- 
securities-studies/en/publications/risk-and-resilience-reports/details.html?id=/m/a/p/p/mapping_social_ vulnerability_in_switzerl

Quarantelli EL (1992) The importance of thinking of disasters as social phenomena (no. DRC preliminary paper \#184). Newark, DE. http://udspace.udel.edu/handle/19716/572\#files-area. Accessed 17 February 2020

Roth F, Eriksen C, Prior T (2017) Understanding the root causes of 'natural' disasters. The Conversation June 27. http://theconversation.com/understanding-the-root-causes-of-natural-disasters-80017

Roth F, Prior T, Maduz L, Wolf A (2018) Social vulnerability in affluent contexts: an in-depth analysis of social vulnerability in Zürich. Risk and Resilience Report, ETH Zürich https://css.ethz.ch/en/services/digitallibrary/articles/article.html/d510fef7-bfbe-446d-bfef-cd39b26db87d

Rühlemann A, Jordan JC (2019) Risk perception and culture: implications for vulnerability and adaptation to climate change. Disasters. https://doi.org/10.1111/disa.12429

Rumbach A, Makarewicz C, Németh J (2016) The importance of place in early disaster recovery: a case study of the 2013 Colorado floods. J Environ Plan Manag 59(11):2045-2063

Rumbach A, Sullivan E, Makarewicz C (2020) Mobile home parks and disasters: understanding risk to America's third housing type. Natural Hazards Review 21(2):05020001. https://doi.org/10.1061 $/($ ASCE)NH.1527-6996.0000357

Schumacher E, Strobl I (2011) Economic development and losses due to natural disasters: the role of hazard exposure. Ecol Econ 72:97-105

Scolobig A, Prior T, Schröter D, Jörin J, Patt A (2015) Towards people-centred approaches for effective disaster risk management: balancing rhetoric with reality. Int J Disaster Risk Reduct 12:202-212

Simon GL (2014) Vulnerability-in-production: a spatial history of nature, affluence, and fire in Oakland, California. Ann Assoc Am Geogr 104(6):1199-1221

Simon GL (2017) Flame and fortune in the American west: urban development, environmental change, and the great Oakland Hills fire. University of California Press, Berkeley

Smit B, Wandel J (2006) Adaptation, adaptive capacity and vulnerability. Glob Environ Chang 16(3):282-292

Sword-Daniels V, Eriksen C, Hudson-Doyle EE, Alaniz R, Adler C, Schenk T, Vallance S (2018) Embodied uncertainty: living with complexity and natural hazards. J Risk Res 21(3):290-307

Tanner T, Lewis D, Wrathall D, Bronen R, Cradock-Henry N, Huq S, Lawless C et al (2015) Livelihood resilience in the face of climate change. Nat Clim Chang 5(1):23-26

Tapsell S (2010) Socio-psychological dimensions of flood risk management. In: Pender G, Faulkner H (ed) flood risk science and management. doi: https://doi.org/10.1002/9781444324846.ch20

Tapsell SM, Penning-Rowsell EC, Tunstall SM, Wilson T (2002) Vulnerability to flooding: health and social dimensions. Philos Trans R Soc Lond 360:1511-1525

Thomalla F, Downing T, Spanger-Siegfried E, Han G, Rockström J (2006) Reducing hazard vulnerability: towards a common approach between disaster risk reduction and climate adaptation. Disasters 30(1):39-48

Thomalla F, Boyland M, Johnson K, Ensor J, Tuhkanen H, Gerger Swartling A, Han G, Forrester J, Wahl D (2018) Transforming development and disaster risk. Sustainability 10:1458

Tierney K (2014) The social roots of risk: producing disasters, Promoting Resilience. Stanford University Press, Stanford

UN (2015) The 17 sustainable development goals (SDGs) of the 2030 agenda for sustainable development. United Nations, Geneva https://www.un.org/sustainabledevelopment/

UNDRR (2005) Hyogo framework for action 2005-2015: building the resilience of nations and communities to disasters. United Nations Office for Disaster Risk Reduction, Geneva https://www.unisdr. org/we/inform/publications/1037

UNDRR (2015) Sendai framework for disaster risk reduction 2015-2030. United Nations Office for Disaster Risk Reduction, Geneva https:/www.unisdr.org/we/coordinate/sendai-framework

UNDRR (2017) Component of risk: vulnerability. UNISDR Terminology. United Nations Office for Disaster Risk Reduction, Geneva https://www.preventionweb.net/risk/vulnerability

UNFCCC (2015) Paris Agreement. United Nations Framework Convention on Climate Change, Geneva https://unfccc.int/process-and-meetings/the-paris-agreement/what-is-the-paris-agreement

Veland S, Howitt R, Dominey-Howes D (2010) Invisible institutions in emergencies: evacuating the remote indigenous community of Warruwi, Northern Territory Australia, from Cyclone Monica. Environ Hazards 9:197-214

Veland S, Howitt R, Dominey-Howes D, Thomalla F, Houston D (2013) Procedural vulnerability: understanding environmental change in a remote indigenous community. Glob Environ Chang 23:314-326

Walker HM, Culham A, Fletcher AJ, Reed MG (2019) Social dimensions of climate hazards in rural communities of the global north: an intersectionality framework. J Rural Stud 72:1-10

Watts N, Adger NW, Agnolucci P et al (2015) Health and climate change: policy responses to protect public health. Lancet 386:1861-1914

Wilkinson RG (2002) Unhealthy societies: the afflictions of inequality. Routledge, London

Wisner B (1993) Disaster vulnerability: scale, power, and daily life. GeoJournal 30(2):127-140 
Wisner B (1998) Marginality and vulnerability: why the homeless of Tokyo don't 'count' in disaster preparations. Appl Geogr 18(1):25-33

Wisner B (2010) Marginality. In: Bobrowski P (ed) Encyclopedia on natural hazards. Springer, Berlin, p 651

Wisner B, Blaikie P, Cannon T, Davis I (2004) At risk: natural hazards, people's vulnerability and disasters, 2nd edn. Routledge, London

Zuniga D, Campos V (2013) Chile's middle class survives on shaky ground. DW. https://www.dw. com/en/chiles-middle-class-survives-on-shaky-ground/a-16527618. Accessed 16 February 2020

Publisher's note Springer Nature remains neutral with regard to jurisdictional claims in published maps and institutional affiliations.

\section{Affiliations}

\section{Christine Eriksen ${ }^{1,2} \cdot$ Gregory L. Simon $^{3}$ - Florian Roth ${ }^{1,4} \cdot$ Shefali Juneja Lakhina ${ }^{2,16}$ • Ben Wisner ${ }^{5,6} \cdot$ Carolina Adler $^{7} \cdot$ Frank Thomalla $^{8} \cdot$ Anna Scolobig $^{9} \cdot$ Kate Brady $^{10,11}$. Michael Bründl $^{12} \cdot$ Florian Neisser $^{13} \cdot$ Maree Grenfell $^{14} \cdot$ Linda Maduz $^{1} \cdot$ Timothy $^{2}$ Prior ${ }^{1,15}$}

1 Center for Security Studies, Swiss Federal Institute of Technology (ETH), Zürich, Switzerland

2 Australian Centre for Culture, Environment, Society and Space (ACCESS), School of Geography and Sustainable Communities, University of Wollongong, Wollongong, Australia

3 Department of Geography and Environmental Sciences, University of Colorado Denver, Denver, CO, USA

4 Fraunhofer Institute for Systems and Innovation Research ISI, Karlsruhe, Germany

5 Institute for Risk and Disaster Reduction, University College London, London, UK

6 Environmental Studies Department, Oberlin College, Oberlin, OH, USA

7 Mountain Research Initiative, University of Bern, Bern, Switzerland

8 Climate and Disaster Risk Research and Consulting, Sydney, Australia

9 Environmental Governance and Territorial Development Institute, University of Geneva, Geneva, Switzerland

10 Australian Red Cross, North Melbourne, VIC, Australia

11 University of Melbourne, Melbourne, VIC, Australia

12 WSL Institute for Snow and Avalanche Research SLF, Davos Dorf, Switzerland

13 Fraunhofer Institute for Technological Trend Analysis INT, Euskirchen, Germany

14 Resilient Melbourne, Melbourne, VIC, Australia

15 Control Centre, IT, Network \& Infrastructure, Swisscom (Schweiz) AG, Ittigen, Switzerland

16 Wonder Labs, San Jose, CA, USA 